\title{
Az Európai Unió Közép-Ázsia-stratégiájának kritikai elemzése
}

\section{A Critical Analysis of the European Union's Central Asia Strategy}

2019 júniusában az Európai Unió Tanácsa elfogadta új Közép-Ázsia-stratégiáját. A Keleti Partnerség mellett a közép-ázsiai térség az EU egyik kiemelt fókuszterülete, így a kapcsolatok fejlesztési stratégiájának kijelölése, pontositása mindenképpen szükséges volt. Tanulmányomban az azóta eltelt időszak fejleményeit figyelembe véve szeretném bemutatni, miért erösíti a gyenge EU képét a dokumentum, és miért nem alkalmas az EU talán nem is létező céljainak elérésére. Hipotézisem, hogy 1. az EU-naknincs világos, valós stratégiája a térség kapcsán, így 2. a térségben érdekelt nagy-és középhatalmak játszmájából vesztesen kerül ki, és 3. a térségben rejló gazdasági potenciált nem tudja kiaknázni. Tanulmányomat nyílt forrásból származó információk elemzésével, valamint mélyinterjúk értékelésével készitettem el. Vizsgálatom eredményei azt mutatják, hogy csekély esély van az EU erôs szereplővé válására a térségben.

Kulcsszavak: Közép-Ázsia, stratégia, külpolitika, soft power

The Council of the European Union adopted in June 2019 its new EU Strategy on Central Asia. Besides the Eastern Partnership, the Central Asian region is one of the most focused areas of the EU, so determining and shaping the development priorities were of paramount importance. In this study, based on the developments and feedbacks in the recent months, I would like to demonstrate how the weak EU image will be reinforced due to this document and why it is not suitable for reaching the goals of EU, which may not even exist. My hypotheses are: 1) in fact, the EU does not have any clear and real strategy focusing on Central Asia, 2) the EU is losing out on the game of big and middle powers interested in the region, 3) the EU cannot exploit the economic potentials of the region.

Keywords: Central-Asia, strategy, foreign policy, soft power

Vasa László a Széchenyi István Egyetem kutatóprofesszora, a Külügyi és Külgazdasági Intézet főtanácsadója és vezető kutatója. E-mail: laszlo.vasa@ifat.hu 


\section{Bevezetés}

2019. július 7-én az Európai Unió Kirgizisztán fővárosában, Biskekben mutatta be az előző hónapban, június 17-én Brüsszelben a Tanács által elfogadott új Közép-Ázsiastratégiáját, ${ }^{1}$ amely valójában a korábbi, 2007-es verzió frissített, aktualizált változatának tekinthető. Már a korábbi verziót is sok kritika érte: egyrészt a világos célok hiánya, másrészt Európából nézve fontosnak tűnő, de a kapcsolatok minősége és a közép-ázsiai országok szempontjából marginális témák miatt. Miközben a legutóbb meghirdetett stratégiát a korábbi stratégia mai viszonyokhoz jobban igazodó cél- és eszközrendszerének szánták, a fókusz-cél-tartalom összhangja továbbra is hiányzik. Többen, nem csupán az unión kívül, hanem a tagországok részéről is kritizálják az EU-t külpolitikai gyengesége, határozatlansága és marginális témák külkapcsolati priorizálása miatt. (Molnár, 2018) Erre az érzésre mintha a dokumentumot elfogadó uniós intézmény is ráerősítene, hiszen az egyéves előzetes konzultáció ellenére sem sikerült teljesen új, az EU érdekeit szem előtt tartó, az érdekelt szereplőket bevonó, a megcélzott térség államainak érdekeit és történelmi sajátosságait figyelembe vevő stratégia megalkotása.

Közép-Ázsia fogalma alatt több nemzetközi értelmezés létezik - többek között történelmi, szovjet definíció, az UNESCO által használt értelmezés és a modern politikaföldrajzi értelmezés. Közép-Ázsia mint önálló földrajzi elnevezés először 1843-ban szerepelt a porosz Alexander von Humboldt könyvében, aki a földrajztudomány egyik alapítójának számít. ${ }^{2}$ A kialakult értelmezés szerint Közép-Ázsia alatt a tengeri kijárattal nem rendelkező ázsiai régiókat értjük. Ezt a logikát követve az UNESCO definíciója szerint a közép-ázsiai régióban benne van Kazahsztán, Kirgizisztán, Üzbegisztán, Tádzsikisztán, Türkmenisztán, Mongólia és Afganisztán is. (Dani et al., 1992-2005:3-16) A 20. században használt szovjet definíció Közép-Ázsia részének tekintett egyes kínai területeket is (Belső-Mongólia, Tibet és Xinjiang tartományok), viszont Kazahsztánt nem. ${ }^{3}$ E tanulmányban Közép-Ázsia leginkább elterjedt és nemzetközileg elfogadott definícióját használom, amely alapján a régió országai közé öt állam sorolható: Kazahsztán, Kirgizisztán, Üzbegisztán, Tádzsikisztán, Türkmenisztán. ${ }^{4}$ Ezek posztszovjet utódállamok, amelyek a Szovjetunió 1991-es összeomlásával nyerték el függetlenségüket, és amelyek jelenlegi határai az elmúlt században alakultak ki, a szovjet rendszer alatti többszöri módosítások eredményeként. (Bendarzsevszkij-Eszterhai, 2019)

A Szovjetunió felbomlása után Közép-Ázsia ismét előtérbe került geopolitikai szempontból, a nagyhatalmak fokozottan érdeklődtek a térség iránt. Az új szereplők Oroszország mellett az USA, Kína, Törökország, India, illetve gazdasági szempontból az Európai Unió, prioritásaik pedig a régió katonai stratégiai helyzete mellett különösen a kereskedelmi útvonalak, az energiahordozók és ásványkincsek feletti befolyás megszerzése.

www.consilium.europa.eu/media/39778/st10221-en19.pdf (A letöltés dátuma: 2020. 01. 25.)

Alexander von Humboldt háromkötetes, 1843-ban megjelent múvének a címe Asia Centrale, amelyet Humboldt I. Miklós orosz cárnak dedikált.

3 Lásd Nagy Szovjet Enciklopédia (2012). ZAO BUKA. (Az 1926-1990 közötti kiadások javított, elektronikus verziója.) Elérhető: https://slovar.cc/enc/bse/2057489.html (A letöltés dátuma: 2020. 01. 20.) Az EU-s terminológia is ezt a kategorizálást követi. Lásd: www.europarl.europa.eu/factsheets/en/ sheet/178/central-asia (A letöltés dátuma: 2020. 01. 22.) 
A térség stabilitásának megőrzése viszont rendkívül fontos cél a versengő nagyhatalmak számára is. (Szálkai, 2014)

Tanulmányomban elemzem, milyen eredmények érhetők el az Európai Unió KözépÁzsia-stratégiájával, milyen szerep jut az EU-nak a térségben aktív szerepet játszó nagyés középhatalmak játszmájában, és mik a lehetőségei az EU tagállamainak egy differenciált külpolitika és külgazdasági kapcsolatrendszer kiépítésére.

Hipotézisem, hogy 1. az EU-nak nincs világos, valós stratégiája a térség kapcsán, így 2. a térségben érdekelt nagy- és középhatalmak játszmájából vesztesen kerül ki, és 3. a térségben rejlő gazdasági potenciált nem tudja kiaknázni.

\section{EU-Közép-Ázsia kapcsolatok}

Az EU magasabb szintre lépett a közép-ázsiai partnerekkel kötött korábbi partnerségi és együttműködési megállapodások vonatkozásában. 2015 decemberében új EPCA-t (Kiemelt Partnerségi és Együttmúködési Megállapodás) írt alá Kazahsztánnal. ${ }^{5}$ A Kirgizisztánnal kötött EPCA-t ${ }^{6} 2019$ júliusában fogadták el, míg az Üzbegisztánnal folytatott tárgyalásokat 2018 novemberében kezdték meg. ${ }^{7}$ E két utóbbi országnak 1999 óta van az EU-val partnerségi és együttmúködési megállapodása. Tádzsikisztán, amelynek PCA-ja (Partnerségi és Együttmüködési Megállapodás - Partnership and Cooperation Agreement) 2010 óta hatályos, ${ }^{8}$ szintén érdeklődését fejezte ki az EPCA megkötése iránt. ${ }^{9}$ Az EU és Türkmenisztán közötti kapcsolatokat a kereskedelemről és a kereskedelemmel kapcsolatos kérdésekről szóló 2010. évi ideiglenes megállapodás szabályozta egészen addig, amíg 2019-ig a PCA-t a tagállamok alá nem írták (a késedelmet az EU részéről felmerült, emberi jogok helyzetével kapcsolatos aggályok jelentették).

Kazahsztán kiemelt fontosságú az EU olajimportja szempontjából (kb. 8\%), Türkmenisztán pedig jelentős szerepet tölt be a földgázellátásban. A szomszédos afganisztáni konfliktus és a kapcsolódó biztonsági kihívások miatt az EU támogatja a közép-ázsiai partnereket a határbiztonság fokozása és a kábítószer-kereskedelem elleni küzdelem terén. 2013 óta rendszeressé vált az EU és Közép-Ázsia országai közötti magas szintű politikai és biztonsági párbeszéd. Közép-Ázsia valamennyi államában van EU-diplomáciai képviselet, a legutóbbi 2019 júliusában nyílt meg Türkmenisztán fővárosában, Aşgabatban. ${ }^{10}$

\footnotetext{
https://eur-lex.europa.eu/legal-content/HU/TXT/PDF/?uri=CELEX:32016D0123\&from=EN (A letöltés dátuma: 2020. 01. 28.)

$6 \quad$ EU - Kyrgyz Republic Enhanced Partnership and Cooperation Agreement. Elérhető: https://eeas. europa.eu/sites/eeas/files/epca_factsheet.pdf (A letöltés dátuma: 2020.02. 01.)

EU - Uzbekistan Enhanced Partnership and Cooperation Agreement (EPCA). Elérhető: https://trade. ec.europa.eu/doclib/docs/2019/october/tradoc_158407.pdf (A letöltés dátuma: 2020. 01. 27.)

$8 \quad$ EU - Tajikistan Partnership and Cooperation Agreement. Elérhető: www.europarl.europa.eu/delegations/en/dcas/documents/eu-texts?tabCode=tajikistan (A letöltés dátuma: 2020. 01. 25.) www.caspianpolicy.org/eu-and-central-asian-opportunities-european-council-president-highlightspositive-relations-during-central-asia-tour/ (A letöltés dátuma: 2020. 01. 25)

10 www.europarl.europa.eu/factsheets/hu/sheet/178/kozep-azsia (A letöltés dátuma: 2020. 01. 27.)
}

Európai Tükör 2020/1. 
A közép-ázsiai országok támogatást kaphatnak a Fejlesztési és Együttműködési Eszközalapból:11 1028 millió euró a 2014-2020 közötti időszakra (a 2007-2013 közötti 750 millió euró volt), amely magában foglalja mind a bilaterális megállapodás alapján járó támogatásokat, mind a regionális programokat (360 millió euró). A támogatások az oktatásra, a regionális biztonságra, a természeti erőforrások fenntartható kezelésére és a társadalmi-gazdasági fejlődésre összpontosítanak. Kazahsztán és Türkmenisztán már nem jogosultak a DCI bilaterális részeire, mivel elérték a közepes jövedelmú ország státusát, ám továbbra is hozzáférhetnek a regionális programokhoz. A demokrácia és az emberi jogok európai eszköze (EIDHR/European Instrument for Democracy and Human Rights) valamennyi államban múködik, kivéve Türkmenisztánt, ahol például a civil társadalmi szervezetek száma nagyon alacsony, rosszul szervezett és túl szigorúan ellenőrzött.

\section{Az EU Közép-Ázsia-stratégiája}

Az EU Közép-Ázsia-stratégiája Az EU és Közép-Ázsia: új lehetooségek és erôsebb partnerség (The EU and Central Asia: New Opportunities for a Stronger Partnership) címú dokumentum formájában fogadták el és kommunikálták 2019. május-június folyamán. ${ }^{12}$ A dokumentum azon a feltételezésen alapul, hogy a közép-ázsiai térség öt állama és az EU között hosszú, jelentős kölcsönös érdekeken alapuló kapcsolat áll fenn („have a longstanding relationship based upon strong mutual interests"). Az EU-t szemmel láthatóan és érthetően lelkesítik az előző Közép-Ázsia-stratégia ${ }^{13}$ (2007) óta eltelt időszakban, különösen a közelmúltban bekövetkezett változások és reformok, főként Üzbegisztán vonatkozásában („Some of today's developments in Central Asia have further opened up new opportunities for taking the EU-Central Asia partnership forward. Reform processes in the region have triggered calls for political recognition and support for modernisation from the EU.”). A térség országai megbízható partnerként számíthatnak az EU-ra a reformok és a gazdasági átalakulás (Li et al., 2019), a világgazdaságba való integráció, a minőségi beruházások és a korszerű technológiák terén, és az EU természetes támogatója a térségi együttműködéseknek.

11 Development Cooperation Instrument (DCI). Lásd bővebben: www.europarl.europa.eu/RegData/etudes/BRIE/2017/608764/EPRS_BRI(2017)608764_EN.pdf (A letöltés dátuma: 2020. 01. 25.)

12 Joint Communication to the European Parliament and the Council. The EU and Central Asia: New Opportunities for a Stronger Partnership. Elérhető: https://eeas.europa.eu/sites/eeas/files/joint_communication_-_the_eu_and_central_asia_-_new_opportunities_for_a_stronger_partnership.pdf (A letöltés dátuma: 2020. 02.03.)

13 The EU and Central Asia: Strategy for a New Partnership, 10113/07 of 31 May 2007. 
Az EU Közép-Ázsia-stratégiája három, egymással szoros kapcsolatban lévő és egymást erősítő prioritásra épít:

\section{Partnerség az ellenállóképességért, rugalmasságért}

Az EU partnerként fog működni a közép-ázsiai országokkal a társadalmi-gazdasági céljaikat és biztonságukat érintő kihívások előrejelzésében és kezelésében, valamint a reformok és a modernizáció képességének erősítésében. Támogatja a demokráciát, az emberi jogok érvényesülését és a jogállamiságot, fokozza az együttmúködést az éghajlatváltozással kapcsolatos kötelezettségvállalások végrehajtása és a régiót érintő környezeti kihívások kezelése érdekében, erősíti a migrációval kapcsolatos együttmüködést. Ezen belül:

- a demokrácia, az emberi jogok és a jogállamiság előmozdítása;

- szorosabb együttműködés a határigazgatás, a migráció és a mobilitás, valamint a közös biztonsági kihívások kezelése terén;

- az ellenállóképesség fokozása a környezetvédelem, a klímaváltozás és a vízgazdálkodás terén.

\section{Partnerség a jólétért}

Az EU támogatja a térség jelentős növekedési potenciáljának felszabadítását a versenyképes magánszektor fejlődésének elősegítésével, valamint segítséget nyújt a nyitott befektetési környezet megteremtéséhez. Együttműködik a tudás és készségek erősítésében, a kutatás-fejlesztésben és az innovációban, különös figyelmet fordítva a fiatalokra. Arra törekszik, hogy megszüntesse a régión belüli kereskedelem és beruházások szerkezeti korlátait, támogatja a még nem tag közép-ázsiai államok csatlakozását a Kereskedelmi Világszervezethez (WTO) és előmozdítja a fenntartható kapcsolatokat. Ezen belül:

- stabil partnerség a gazdasági reformokban;

- a régión belüli és régiók közötti kereskedelem és beruházások elősegítése;

- a fenntartható (infrastrukturális) kapcsolatok elősegítése.

\section{Partnerség a kölcsönös megértésért}

Az EU együttműködik Közép-Ázsia országaival a partnerségi viszonyok megerősítése, a politikai párbeszéd fokozása és a civil társadalom erősítése érdekében. Az EU továbbra is a régió vezető fejlesztési, segélyezési partnere kíván maradni. Erősíti a nyilvános diplomáciát, hangsúlyozva a partnerség előnyeit a régió és lakosai számára. Ezen belül:

- a partnerség struktúráinak megerősítése, a civil társadalom és a parlamentek bevonása a folyamatba;

- partnerség a nagyobb hatás eléréséért (például ENSZ 2030 Fenntarthatósági Célok). 


\title{
Az EU Közép-Ázsia-stratégiájának geopolitikai kontextusa
}

\begin{abstract}
Ahhoz, hogy világosan lássuk az EU mozgásterét a közép-ázsiai régióban, szükséges áttekintenünk a szereplőket, illetve az azok által létrehozott szervezeteket.

A közép-ázsiai térség a történelem folyamán mindig is a közeli vagy távoli hatalmak játszmáinak terepe volt. Következett ez földrajzi, kulcsfontosságú elhelyezkedéséből: a térség a Kelet és Nyugat között, logisztikailag szinte megkerülhetetlen státuszban volt és van. Fokozta mindezt a múlt században felfedezett, a modern ipar szempontjából nélkülözhetetlen erőforrások bősége. ${ }^{14}$ És természetesen nem hagyhatjuk figyelmen kívül a környező hatalmak időről időre feltörő terjeszkedési szándékait (hiszen a birodalmak létezésének alapelve és létfeltétele a folyamatos terjeszkedés): Perzsia, Oroszország, Kína, de még Törökország is hajlamos volt hagyományos befolyási övezetnek tekinteni Közép-Ázsiát. A régió a Selyemút fontos szakaszait foglalta magában; már az 1800-as évek elején a cári Oroszország expanziójának fontos terepévé vált, amely hagyomány a szovjet időszakban is folytatódott (Gyene, 2018); a legújabb korban pedig az USA (Afganisztán és a nyersanyagokban rejlő üzleti lehetőségek miatt) és Kína (természetes gazdasági, populációs, expanzív és logisztikai motiváltságú terjeszkedése okán) is felfedezte magának a régiót.
\end{abstract}

\section{Kina}

Kína szempontjából a közép-ázsiai térség, különösen Kazahsztán szerepe az Övezet és Út (Belt and Road - BRI) stratégiai programban kulcsfontosságú ${ }^{15}$ (Gyene, 2018), a szárazföldi közlekedési korridorok és az energiaellátás szempontjából jelentős gázellátás miatt tulajdonképpen nélkülözhetetlen. Ez motiválja Kína nem teljesen önzetlen befektetéseit a vasúthálózat fejlesztésébe Kazahsztánban, valamint a Türkmenisztán és Kína közötti földgázvezeték építésének finanszírozásában. Kína politikai befolyása a közép-ázsiai régióban továbbra is limitált Oroszországhoz képest. Kína átfogó stratégiai megállapodást fogadott el Kazahsztánnal 2013-ban, amely a kínai diplomáciában az egyik legszorosabb bilaterális kapcsolatra utal. Kirgizisztán, Tádzsikisztán, Türkmenisztán és Ü̉zbegisztán stratégiai partnerekként jelennek meg, ami mutatja, hogy Peking számára ezek az országok kisebb jelentőségűek, annak ellenére, hogy Kína gázvezeték építését finanszírozta Türkmenisztánból az energiaellátás biztonságának növelése érdekében. ${ }^{16}$

\footnotetext{
14 Lásd még Közép-Ázsia Természeti Erőforrások Atlasza: Energy Resources. Enormous Development Potential. Elérhető: www.carecprogram.org//uploads/Energy-Resources-Enormous-Development-Potential.pdf (A letöltés dátuma: 2020. 02. 06.)

15 Bővebben lásd: www.worldbank.org/en/news/feature/2019/03/11/belt-and-road-initiative-in-central-asia-and-the-caucasus (A letöltés dátuma: 2020. 02. 06.)

16 Ministry of Foreign Affairs of China (2018). Elérhető: www.fmprc.gov.cn/mfa_eng/gjhdq_665435/ (A letöltés dátuma: 2020. 02. 26.)
} 
Kína egyik legfontosabb nemzetközi kezdeményezése, amely intézményként és hatásában is figyelemre méltó, a Sanghaji Együttműködési Szervezet (Shanghai Cooperation Organization - SCO). ${ }^{17}$ Elődje az 1996-ban Kína, Oroszország, Kazahsztán, Kirgizisztán és Tádzsikisztán által életre hívott „sanghaji ötök”. Az SCO 2001-es megalakulásakor Üzbegisztánnal bővült ki az új szervezet, amelynek viszont továbbra sem tagja Türkmenisztán. A Sanghaji Együttmúködést kezdetben az elemzők úgy értékelték, mint a régió felosztását Oroszország és Kína által: „míg politikai és katonai értelemben a térség továbbra is orosz befolyás alatt marad, addig Kína gazdasági hozzáférést kap a térséghez. Azonban az orosz gazdasági és demográfiai problémák miatt egyre inkább az a meggyőződés vált általánossá, hogy az egyezmény hosszabb távon a gazdasági tényezők kiemelt szerepe miatt Kínának kedvez”. (Bendarzsevszkij-Eszterhai, 2019) A szervezet 2017-es, Indiával és Pakisztánnal való kibővítésében az együttmüködés a földrész túlnyomó részét integráló szervezetté vált. ${ }^{18}$ Emiatt azonban kétséges, hogy valóban egyértelműen és kizárólag Kína érdekeit szolgálja-e a jövőben.

Az elsősorban biztonságpolitikai együttműködést célzó SCO mellett megemlítendő a gazdasági fókuszú, Közép-Ázsiát jelentősen érintő, Kínából kiinduló geostratégiai kezdeményezés, az Egy Övezet, Egy Út vagy Övezet és Út (One Belt One Road - OBOR vagy Belt and Road - BRI). A kezdeményezést Xi Jinping elnök indította el 2013 őszén, Kazahsztánban, amely tény önmagában jelzésértékű. Célja szerint az eurázsiai kapcsolatrendszert új alapokra kell helyezni, ami egyben az egyes nemzeti szintű politikák összehangolását is jelenti, valamint az e célt szolgáló új infrastrukturális beruházásokat, a kereskedelem akadályainak lebontását, a pénzügyi integrációt és a nemzetek közötti kapcsolatok erősítését, az állampolgárok szintjén is. A definiált gazdasági folyosók jelntős szerepet játszanak a programban, ebből a szempontból Közép-Ázsia tulajdonképpen megkerülhetetlen: Az Új Eurázsiai Földhíd Gazdasági Folyosó összeköttetést biztosít Kína és az Európai Unió között. ${ }^{19}$ A régió országai támogatják az Egy Övezet, Egy Út programot, mert abban bíznak, hogy jelentős hasznuk származik az interregionális kereskedelem bővüléséből, valamint a növekvő kínai infrastrukturális beruházásokból. Ennek egyik fontos jele, hogy Tádzsikisztán kivételével valamennyi közép-ázsiai állam a legmagasabb szinten vett részt a 2019-es, Pekingben megtartott Övezet és Út fórumon. (Bendarzsevszkij-Eszterhai, 2019)

\section{$E G U$}

A Nazarbajev kazah elnök által már 1994-ben kezdeményezett Eurázsiai Gazdasági Unió (EGU) újfajta képződményt jelent a nemzetközi integrációs típusú szervezetek körében. Bár 2011-ben vámunióként kezdett el működni, 2015 óta, a következő integrációs fokozatra lépve, gazdasági unióként tevékenykedik. Létrehozása a klasszikus geopolitikai

\footnotetext{
17 http://eng.sectsco.org/ (A letöltés dátuma: 2020. 01. 25.)

18 https://thediplomat.com/2019/03/india-pakistan-tensions-test-the-shanghai-cooperation-organizations-mettle/ (A letöltés dátuma: 2020. 01. 28.)

19 Az unió külön stratégiával rendelkezik az Európa-Ázsia konnektivitás javítására. Lásd: https:// eeas.europa.eu/sites/eeas/files/joint_communication___connecting_europe_and_asia_-_building_ blocks_for_an_eu_strategy_2018-09-19.pdf (A letöltés dátuma: 2020. 01. 26.)
} 
megfontolások mellett egy tudatos, hosszú távú gazdasági és geopolitikai terven alapul. Ebben az értelemben pedig az EGU alapítása a tagországok (Belarusz, Kazahsztán, Kirgizisztán, Oroszország, Örményország) közötti gazdasági kapcsolatok szorosabbá tételét is szolgálta, valamint azok nemzetgazdaságainak modernizálását egy olyan gazdasági környezet kialakításával, amely alkalmassá teszi őket a globalizáció kihívásainak való megfelelésre. Gazdasági szempontból az integráció középpontjában az egységes termék-, szolgáltatás-, tőke- és munkaerőpiac megteremtése áll. Az Eurázsiai Gazdasági Unió tovább erősítette az integrációs struktúráját az EGU Bíróság, az Eurázsiai Fejlesztési Bank és az Eurázsiai Stabilizációs és Fejlesztési Alap létrehozásával.

\section{Oroszország}

Oroszország a rendszerváltás után hosszú ideig nem szorgalmazta a posztszovjet térség országaival való kapcsolat szorosabbra füzését. Az 1990-es években gazdasága gyenge és sérülékeny volt, de mivel szomszédai ennél is gyengébbnek bizonyultak, az ország a (relatíve) hatalmas gazdasági, politikai és katonai súlyára tudott támaszkodni annak érdekében, hogy befolyásolja a környékbeli fejleményeket. Oroszország pozíciója a térségben tehát csak a 2000-es évek elejétől kezdett gyengülni és meginogni, amikor a nyugati országok és szervezetek egyre aktívabbá váltak, és befolyásra törekedtek a hagyományosan orosz érdekszférában. Ekképpen a balti államok 2004-ben EU- és NATO-tagokká váltak, az első, orosz területet elkerülő olaj- és gázvezetékek pedig nyugati vállalatok segítségével épültek ki. Emellett Kína is elkezdte kiterjeszteni gazdasági befolyását Közép-Ázsiában.

Moszkva regionális gazdasági integrációt erőltető döntése érthető reakció volt ezekre a folyamatokra. Habár elsődleges érdeke az integrációban mindeddig nem gazdasági (az orosz kereskedelemnek mindössze 6 százalékát teszi ki az EGU-tagokkal folytatott kereskedelem), hanem geopolitikai jellegú volt, amely téren minél nagyobb előny megszerzésére törekedett. Vagyis Oroszország a gazdasági unió létrehozásával saját világpolitikai helyzetét akarja megerősíteni a globális hatalmi szcénában. Moszkva logikája szerint az eurázsiai regionális integráció kiépítése nem megy szembe a globalizációs folyamatokkal, még annak ellenére sem, hogy a vámtarifákat széles körben, jelentősen emelték a nem EGU-tagok számára - ami a regionális protekcionizmust támogatja (mindez tisztán tapasztalható az agrártermékek esetében). Sőt, éppen ellenkezőleg, az orosz gondolkodás szerint a regionális gazdasági szervezetek megteremtése elősegíti a globális kereskedelmet és a nemzetközi munkamegosztást. A korábbi, lazább jellegű együttműködésekkel ellentétben ez most a közös gazdasági unión keresztül valósul meg. Mindez egybevág egy másik fontos orosz külpolitikai célkitǔzéssel, ahol az unió mint integráló kapcsolat jelenik meg, egyfajta hídként Európa és Ázsia között. A közlekedési projektek (beleértve a nagysebességű és teherkapacitású vasútvonalak építését is) kiemelten szerepelnek a napirenden, és Oroszország biztosra veszi, hogy az EGU fontos szereplője lesz a kínai Övezet és Út kezdeményezésnek. (Ilyash-Vasa, 2019)

Meg kell jegyezni azt is, hogy a Szovjetunió megszűnésével egyidőben létrejött Független Államok Szövetségének (FÁK) a $9+1$ tagjából $4+1$ közép-ázsiai tag. Türkmenisztán speciális helyzetben van, mert aláírta ugyan a FÁK alapítószerződését, de nem 
írta alá a tagsági chartát, így hivatalosan „társult tagnak” számít. A FÁK szerepe azonban inkább koordinációs szerepre korlátozódott, és egyfajta együttmúködési platformot jelent a résztvevők számára. Az Eurázsiai Gazdasági Unió létrehozásával, illetve Grúzia és Ukrajna kilépésével a FÁK jelentősége tovább csökkent.

\section{Amerikai Egyesült Államok}

Az Egyesült Államok számára Közép-Ázsia az afganisztáni műveletek idején értékelődött fel, amikor is katonai támaszpontokat is üzemeltetett (például 2014-ig Kirgizisztánban). Gazdasági szempontból természetesen a kiaknázható ásványkincsek teszik számára igazán értékessé a térséget. Mindazonáltal, a rendszerváltás utáni kezdeti fellendülés után - nem függetlenül az orosz nyomástól - a térség államaiban fokozatosan csökken az USA kitermelő vállalatainak operációja. Nem hivatalos hírszerzési források Türkmenisztánt tartják az USA legfontosabb térségbeli stratégiai partnerének, amely tény mindenképpen figyelemre méltó Aşgabat politikai kurzusa (önkényuralom) és kiváló kínai kapcsolatai tükrében. Mike Pompeo amerikai külügyminiszter 2020. februári kazahsztáni látogatása ${ }^{20}$ és találkozója az öt közép-ázsiai állam külügyminisztereivel Nur-Szultanban mindenképpen jelzi az USA határozott szándékát, hogy erôs szereplőként visszatérjen a térségbe. Mindezt természetesen a Trump-féle izolacionista külpolitika mentén kell értenünk, azaz például katonai jelenlétben semmiképpen sem gondolkodnak. Mindazonáltal úgy túnik, az USA stratégiai partnerségi ajánlata csakis akkor jelentene valódi lehetőségeket, ha megszűnne az orosz és kínai befolyás a régióban.

\section{Törökország}

Meg kell említenem még Törökországot mint a térség viszonyaira komoly hatással bíró középhatalmat, amelyet egyes elemzők „csendes hatalomnak” is neveznek. ${ }^{21}$ A türk eredetú testvériség, a közös történelem és nyelvi gyökerek egy olyan befolyást ad Ankara kezébe, amellyel a közelmúltban komoly pozíciókat tudott kiépíteni Közép-Ázsia gazdasági, politikai és oktatási szféráiban. A Türk Tanácsnak (Türkic Council), a török nyelvű országok nemzetközi szervezeti státuszú szövetségének (amelynek Magyarország is megfigyelő státuszú tagja) Türkmenisztán és Tádzsikisztán kivételével a maradék három közép-ázsiai ország tagja;22 a szervezet komoly befolyással bír a térségben. Törökország korábban a nyugati országokkal múködött együtt közép-ázsiai programjaiban, ez azonban nem váltotta be a török reményeket, így napjainkra sokkal inkább itt is az orosz-török együttmúködés jellemző. ${ }^{23}$

\footnotetext{
20 https://thediplomat.com/2020/02/a-new-era-of-strategic-partnership-the-us-engages-to-find-opportunities-in-central-asia/ (A letöltés dátuma: 2020. 01. 22.)

21 www.ispionline.it/en/pubblicazione/power-quiet-turkeys-central-asia-strategy-24069 (A letöltés dátuma: 2020. 01. 28.) www.turkkon.org/en-US/HomePage (A letöltés dátuma: 2020. 02. 03.) www.ispionline.it/en/pubblicazione/power-quiet-turkeys-central-asia-strategy-24069 (A letöltés dátuma: 2020. 01. 28.)
} 


\section{A stratégia kritikai elemzése}

Az EU Közép-Ázsia-stratégiájának bemutatásából és a régió geopolitikai helyzetének elemzéséből tulajdonképpen logikusan következik egy kritikai elemzés, amelyben megpróbálom bizonyítani a bevezetőben felállított hipotéziseimet.

Ha a geopolitikai viszonyok elemzésében leírt nagy- és középhatalmi szándékokat és célokat összehasonlítjuk az EU térségre fókuszáló stratégiájával, hatalmas különbséget látunk. Úgy tûnik, mintha az Európai Unió kivételével minden játékos határozott és tudatos (?) szándékokkal venne részt a „nagy játszmában”.

Ha megvizsgáljuk a három fó program alprogramjait, tulajdonképpen a szokásos EU-terminológia köszön vissza:

- a demokrácia, az emberi jogok és a jogállamiság előmozdítása;

- szorosabb együttmúködés a határigazgatás, a migráció és a mobilitás, valamint a közös biztonsági kihívások kezelése terén;

- az ellenállóképesség fokozása a környezetvédelem, a klímaváltozás és vízgazdálkodás terén;

- stabil partnerség a gazdasági reformokban;

- a régión belüli és régiók közötti kereskedelem és beruházások elősegítése;

- a fenntartható (infrastrukturális) kapcsolatok elősegítése;

- a partnerség struktúráinak megerősítése, a civil társadalom és a parlamentek bevonása a folyamatba;

- partnerség a nagyobb hatás eléréséért (például ENSZ 2030 Fenntarthatósági Célok).

Ez érthető és hasznos volt az EU bővítési folyamataiban érintett államok esetében, de rendkívül nehezen fog müködni közép-ázsiai viszonyok között. A demokrácia fetisizálása a térségben a térségi történelmi ismeretek teljes hiányáról tanúskodik, illetve azt bizonyítja, hogy az EU nem képes okulni Afganisztán és Irak leckéiből. Tekintettel a térség viszonyaira, a nyugati típusú demokrácia számonkérése a klánalapú államokon sokkal inkább rombolja az EU lehetőségeit, mintsem elősegíti. Ráadásul, éppen a nagyobb nyugat-európai államok azok, amelyek skrupulusok nélkül hajlandók a háttérben üzletet kötni ezekkel az országokkal, miközben a nyilvánosság előtt a demokráciát és az emberi jogokat kérik számon. ${ }^{24} \mathrm{Az}$ is nyilvánvaló, hogy a térség döntéshozói szívesebben múködnek együtt olyan partnerrel (Kína), aki nem kéri számon rajtuk a demokratikus intézményrendszert és alapelveket.

A határvédelem, a migrációs és biztonsági kihívásokra való fókuszálás dicséretes, kérdés, mennyi pénzügyi és technikai eszközt tud az EU ehhez hozzárendelni - a magyarországi tapasztalatok ezzel kapcsolatban meglehetősen lesújtók.

A környezeti problémákra való fókuszálás szintén üdvözlendő, hiszen ez valóban az EU egyik fő prioritása és nagyon is létező probléma a közép-ázsiai térségben. (Khan et al., 2020) Mindazonáltal, nem látni a konkrét programokat, és hogy ezek a makroszintű elképzelések hogyan viszonyulnak az adott országok környezetvédelmi stratégiai

$24 \quad$ A francia Bouygues építette a Türkménbasi megrendelésére a térség legnagyobb mecsetét 2004-ben 1 milliárd euróért. 
céljaihoz. A támogatások iránt nyilván létezik komoly abszorpciós képesség, az igazi kérdés azonban a valós hasznosulás.

A gazdasági reformok és a kereskedelemfejlesztés egészen addig üres lózungnak tûnnek, amíg nem látjuk, az egyes országoknak milyen igényei vannak. Hiszen például Kazahsztán nem hasonlítható össze sem Tádzsikisztánnal, sem Türkmenisztánnal, de Kirgizisztán sem Üzbegisztánnal. Hatalmas különbségek vannak ugyanis az egyes országok gazdaságszerkezetei, gazdaságpolitikái, de még gazdaságfilozófiái között is. Azonosítani kell azokat a területeket, ahol olyan hatás érhető el, amely az EU cégei számára is kedvező: befektetési lehetőségeket nyit meg, fokozza a kereskedelmet, csökkenti az országkockázatot. Vajon miért nem nevesíti az EU a stratégiában az Astana International Financial Centre-t (AIFC), ${ }^{25}$ amely nagyon komoly nemzetközi támogatással kíván a térség pénzügyi központjává válni? Mindeközben Kína becslések szerint 22,5 milliárd eurót fektetett Közép-Ázsiába az Övezet és Út (BRI) kezdete óta, szemben a csekély 1 milliárd eurós uniós támogatással. A külkereskedelem terén pedig Kína öt országból négyben a legnagyobb partnerré vált.

A fenntartható infrastrukturális kapcsolatokról is inkább általánosságokat tudunk meg, semmint konkrét terveket. Hogyan tudja az EU saját érdekei mentén fejleszteni a kapcsolódást lehetővé tevő korridorokat úgy, hogy azzal ne a fő versenytársainak kedvezzen? Európába a térségből Oroszországon, Törökországon és a Kaukázuson keresztül vezet az út. Ha pedig az EU a Kaszpi-tenger alatti gázvezetéket (Trans-Caspian Pipeline - TCP) mint lehetséges infrastrukturális projektet szeretné megvalósítani, figyelembe kell venni Irán és Oroszország blokkoló képességét és azt, hogy közben egy hatékonyabb szállítást lehetővé tevő csővezeték épül Oroszország és Németország külön megállapodása alapján, az EU ellenkezése mellett. A térség országait összekötő infrastruktúra fejlesztése is nyilván jó lehetőség az EU építőipari vállalatai számára. Azonban, amíg ezekhez a projektekhez nem kapcsolódik fejlesztési segély vagy hitelforrás, addig az EU nem válhat komoly szereplővé. Vállalatai ugyan nyerhetnek építési tendert, de ez eddig leginkább a török és orosz cégeknek sikerült.

A civil szféra erősítése igen kétélú és kockázatos dolog, ráadásul ezek az országok egész egyszerúen nem olyan jogrendszerrel múködnek, amelyben a civil szervezetek érvényesülhetnek anélkül, hogy a politikába való beavatkozás látszatát keltenék.

A 2030-as ENSZ-fejlesztési célok elérésében való partnerség üdvözlendő, de kevéssé kézzel fogható intézkedéseket jelent, illetve kevéssé jól működő fejlesztési programokat feltételez.

Noha a dokumentum átfogó, kevésbé ambiciózus. Azaz nem hoz új korszakot Közép-Ázsia és az EU viszonyrendszerébe, főleg a külső szereplők régióbeli szerepének fényében. Nem javasol olyan új eszközöket, amelyek jelentősen megváltoztathatják a közép-ázsiai országok egészének vagy néhányának az EU-val fennálló kapcsolatát, például nincs stratégiai partnerség, vízumkönnyítés, kereskedelmi liberalizáció vagy új infrastrukturális kulcsprojektek.

https://aifc.kz/ (A letöltés dátuma: 2020. 01. 25.) Az AIFC-t a Kazakhstan 2050 program keretében, Nazarbajev akkori elnök kezdeményezésére alapították Asztanában (ma Nur-Szultan), a 2017. évi EXPO infrastruktúrájára alapozva, azzal a céllal, hogy innovatív pénzügyi technológiák integrálásával az Eurázsiai Gazdasági Unió, Közép-Ázsia, a Kaukázus, Nyugat-Kína és Mongólia pénzügyi központjává váljon.

Európai Tükör 2020/1. 
Annak ellenére, hogy a stratégiáknak általános megközelítésűnek kell lenniük, ez a dokumentum azt a benyomást kelti, hogy nincs egyértelmú végrehajtási rendszer, és a kitúzött feladatok értékelése sem világos - mik lesznek a siker vagy sikertelenség paraméterei?

Nem egyértelmű, hogy a 2019-es stratégiában meghatározott feladatokhoz milyen pénzügyi forrásokat fognak hozzárendelni. Ez, figyelembe véve az EU 2021-2027 közötti pénzügyi keretéről éppen folyó tárgyalásokat, érthető, azonban az EU közép-ázsiai politikájának legalább hozzávetőleges forrásokat meg kellett volna jelölni a komoly szándék kimutatása érdekében.

A dokumentum azt a benyomást kelti, hogy az EU-tagországok kapcsolataiban és potenciáljában rejlő lehetőségeket nem használták ki teljes mértékben. Az EU tagállamainak nagykövetségei, főkonzulátusai, kulturális központjai és különféle fejlesztési segélyprogramjai vannak a térségben, amelyek erősíthetnék az egész EU-stratégia céljait és az azokhoz rendelt eszközrendszert.

A térségben készített mélyinterjúk ${ }^{26}$ kiértékelése alapján megállapítható, hogy a közép-ázsiai elit nagy része hasonló véleménnyel van az EU-ról. Úgy érzik, hogy az EU gyakorlatilag láthatatlan Közép-Ázsiában, hogy a társadalom számára ismeretlen, hogy bonyolult bürokratikus eljárások jellemzik, és ami talán a legfontosabb, hogy a törekvései meghaladják a tényleges hatalmi potenciálját és teljesítési képességeit. Ennek legvalószínúbb oka az, hogy az EU-ban nem létezik átfogó eurázsiai dimenzió és megközelítés.

\section{Értékelés}

Üdvözlendő, hogy az EU fokozta diplomáciai jelenlétét a térségben, de ezeket határozottan használni is szükséges, mind az öt államban megfelelő személyzettel és helyi kapcsolatokkal ellátott EU-képviseletekkel. Egy dinamikusabb konzultációs mechanizmust lehet bevezetni az EU-delegációkban, például magasan képzett és független közép-ázsiai szakértők bevonásával. Az EU-nak több területen más megközelítésre van szüksége, például a klasszikus diplomácia helyett a segélyezéspolitikára és a gazdaságdiplomáciára helyezve a hangsúlyt. Sokkal jobban összpontosíthatna a fejlesztési támogatásokra és azokra a területekre, amelyekben az EU a legkiválóbb, és amelyekért leginkább csodálják: kultúra, oktatás és regionális együttműködés.

A Visegrádi Csoport országainak támogatniuk és ösztönözniük szükséges az EU puha hatalmának érvényesülést azáltal, hogy hozzájárulnak az emberek közötti kapcsolatokhoz és a gazdasági reformokhoz, de szakértelmüket is jól hasznosítható konkrét területeken, mint például az oktatási és kutatási együttmúködés, vízgazdálkodási, mezőgazdasági vagy biztonsági reformok. Proaktívabban szükséges koordinálni tevékenységeiket saját nagykövetségeik vagy programjaik révén, hogy ezáltal az EU kezdeményezése nagyobb hatást érjen el; egyébiránt a stratégia célkitűzései nem teljesülnek

A strukturált interjúkat 2019 szeptemberében készítettem 18 fővel, akik között egyetemi professzorok, doktoranduszhallgatók, kormányzati tisztviselők, kutatóintézetben dolgozó szakértők és üzletemberek egyaránt voltak. 
a közeli és középtávon. A V4-formátumot sikeres modellként lehet felhasználni egy regionális együttműködés kialakításához is.

Az EU új Közép-Ázsia-stratégiája nem igazán tud elvonatkoztatni a közép-ázsiai országok ellenálló képességének témakörétől. Nyilvánvaló, hogy az EU puha megközelítése a régió gazdasági és politikai folyamatainak befolyásolására csak ennyit tud ebből kihozni. Mindazonáltal, lehetnek olyan területek, akár más hatalmakkal való együttmúködésben, amelyek terén sikerek érhetők el. Ennél többet várni most nem reális. Az új stratégia nem maradhat szándéknyilatkozat, a korábbi stratégia kritikája; azt implementálni kell konkrét, előremutató intézkedések mentén, a térség komplikált geopolitikai viszonyai között.

El kell ismerni, hogy ez a stratégia következménye annak, hogy nincs, jelen viszonyok mellett nem lehet közös EU-külpolitika. Liberális alapelveken nyugvó puha, iteráló megközelítések vannak, azonban ez a kulcsfontosságú régiókban nem lesz elegendő. És természetszerűen következik ebből a helyzetből az, hogy a tagállamok - helyesen és érthető módon - a saját érdekeik mentén, pragmatikus külpolitikát és gazdasági kapcsolatokat építenek a térségben, tulajdonképpen egymás versenytársaiként fellépve.

\section{Felhasznált irodalom}

BendArzsevszkiJ, Anton - Eszterhai, Viktor (2019): Az „újnagyjátszma” Közép-Ázsiában. PAGEO Geopolitikai Kutatóintézet. Elérhető: www.geopolitika.hu/hu/2019/01/22/ az-uj-nagy-jatszma-kozep-azsiaban/ (A letöltés dátuma: 2020. 01. 20)

DAnI, Ahmad Hasan - Masson, Vadim M. - Harmatta, Janos - PuRI, Baij Nath Etemadi, G. F. - LitvinskiJ, Boris A. (1992-2005): History of civilizations of Central Asia. Volume 5. Paris, Unesco.

Gyene Pál (2018): Kína gazdasági felemelkedése és az „új selyemút” percepciói KözépÁzsiában. Külügyi Szemle, 17. évf. 3. sz. 99-115. Elérhető: https://kki.hu/assets/ upload/5_Gyene_Pel.pdf (A letöltés dátuma: 2020. 01. 27.)

ILYASH György - VASA László (2019): Az Eurázsiai Gazdasági Unió helyzete és kilátásai. Külügyi Szemle, 18. évf. 4. sz. 67-85.

Khan, Muhammad Asif - Popp, József - TAlib, Mirza Nouman Ali - LAKner, Zoltán KHAN, Muhammad Atif - OlÁH, Judit (2020): Asymmetric Impact of Institutional Quality on Tourism Inflows Among Selected Asian Pacific Countries. Sustainability, Vol. 12, No. 3. 1-16. DOI: https://doi.org/10.3390/su12031223

Köstem, Seçkin (2019): The Power of the Quiet? Turkey's Central Asia Strategy. Elérhető: www.ispionline.it/en/pubblicazione/power-quiet-turkeys-central-asia-strategy-24069 (A letöltés dátuma: 2020. 01. 28.)

LI, Chunling - Pervaiz, Khansa - Khan, Muhammad Asif - Rehman, Faheem Ur - OlÁH, Judit (2019): On the Asymmetries of Sovereign Credit Rating Announcements and Financial Market Development in the European Region. Sustainability, Vol. 11, No. 23. 1-14. DOI: https://doi.org/10.3390/su11236636

MolnÁr Anna (2018): Az Európai Unió Külkapcsolati rendszere és eszközei. Budapest, Dialóg Campus Kiadó. 
SzÁlKai Kinga (2014): Az EU szerepvállalása Közép-Ázsiában. Nemzet és Biztonság, 7. évf. 5. sz. 51-62.

The EU and Central Asia: Strategy for a New Partnership, 10113/07 of 31 May 2007

\section{Internetes források}

Development Cooperation Instrument (2017). Elérhető: www.europarl.europa.eu/RegData/etudes/BRIE/2017/608764/EPRS_BRI(2017)608764_EN.pdf (A letöltés dátuma: 2020. 01. 25.)

Energy Resources. Enormous Development Potential. Elérhető: www.carecprogram. org//uploads/Energy-Resources-Enormous-Development-Potential.pdf (A letöltés dátuma: 2020. 01. 28.)

EU - KyrgyzRepublic Enhanced Partnership and Cooperation Agreement. Elérhető: https:// eeas.europa.eu/sites/eeas/files/epca_factsheet.pdf (A letöltés dátuma: 2020. 01. 29.)

EU - Tajikistan Partnership and Cooperation Agreement. Elérhető: www.europarl.europa. eu/delegations/en/dcas/documents/eu-texts?tabCode=tajikistan (A letöltés dátuma: 2020. 01. 30.)

EU - Uzbekistan Enhanced Partnership and Cooperation Agreement (EPCA). Elérhető: https://trade.ec.europa.eu/doclib/docs/2019/october/tradoc_158407.pdf (A letöltés dátuma: 2020. 02. 04.)

http://eng.sectsco.org/ (A letöltés dátuma: 2020. 01. 25.)

https://aifc.kz/ (A letöltés dátuma: 2020. 01. 25.)

https://eeas.europa.eu/sites/eeas/files/joint_communication_-_connecting_europe_

and_asia_building_blocks_for_an_eu_strategy_2018-09-19.pdf (A letöltés dátuma: 2020. 01. 26.)

https://eur-lex.europa.eu/legal-content/HU/TXT/PDF/?uri=CELEX:32016D0123\&fr om=EN (A letöltés dátuma: 2020. 01. 25.)

https://thediplomat.com/2019/03/india-pakistan-tensions-test-the-shanghai-cooperation-organizations-mettle/ (A letöltés dátuma: 2020. 01. 28.)

https://thediplomat.com/2020/02/a-new-era-of-strategic-partnership-the-us-engagesto-find-opportunities-in-central-asia/ (A letöltés dátuma: 2020. 01. 22.)

Joint Communication to the European Parliament and the Council. The EU and Central Asia: New Opportunities for a Stronger Partnership. Elérhető: https://eeas.europa. eu/sites/eeas/files/joint_communication_-_the_eu_and_central_asia_-_new_ opportunities_for_a_stronger_partnership.pdf (A letöltés dátuma: 2020. 01. 24.)

Ministry of Foreign Affairs of China (2018). Elérhető: www.fmprc.gov.cn/mfa_eng/ gjhdq_665435/ (A letöltés dátuma: 2020. 02. 26.)

Nagy Szovjet Enciklopédia (2012). ZAO BUKA. Elérhető: https://slovar.cc/enc/bse/20 57489.html (A letöltés dátuma: 2019. 01. 20.)

www.caspianpolicy.org/eu-and-central-asian-opportunities-european-council-president-highlights-positive-relations-during-central-asia-tour/ (A letöltés dátuma: 2020. 02. 05.)

www.consilium.europa.eu/media/39778/st10221-en19.pdf (A letöltés dátuma: 2020. 01. 20.) 
www.europarl.europa.eu/delegations/en/dcas/documents/eu-texts?tabCode=tajikistan (A letöltés dátuma: 2020. 01. 23.)

www.europarl.europa.eu/factsheets/en/sheet/178/central-asia (A letöltés dátuma: 2020. 01. 23.)

www.turkkon.org/en-US/HomePage (A letöltés dátuma: 2020. 02. 03.)

www.worldbank.org/en/news/feature/2019/03/11/belt-and-road-initiative-in-centralasia-and-the-caucasus (A letöltés dátuma: 2020. 02. 06.) 